\title{
THE CASE FOR A FEDERAL PSYCHOTHERAPIST-PATIENT PRIVILEGE THAT PROTECTS PATIENT IDENTITY
}

The case of In re Zuniga ${ }^{1}$ has reawakened the dispute regarding federal judicial recognition of a psychotherapist $^{2}$-patient privilege. ${ }^{3}$ In Zuniga, the United States Court of Appeals for the Sixth Circuit, while recognizing the existence of a psychotherapist-patient privilege protecting confidential communications, held that niere disclosure of a patient's identity was not privileged. ${ }^{4}$ In recognizing the existence of the privilege, the Sixth Circuit joined the Ninth Circuit in a developing split among the courts of appeals on this issue. 5 Yet in refusing to extend the privilege to protect against the disclosure of the identity of a patient receiving psychotherapy, the Zuniga court followed unanimous precedent. ${ }^{6}$

1. 714 F.2d 632 (6th Cir.), cert denied, 464 U.S. 983 (1983). Zuniga affirmed orders of a federal district court holding two psychiatrists in civil contempt for failing to respond appropriately to a subpoena duces tecum issued by a grand jury in connection with an investigation of alleged billing fraud. $I d$. at $635-36,642$. Specifically, the subpoenas ordered the psychiatrists to produce information as to the identity of certain named patients, the dates on which they were treated, and the length of treatinent on each date. Id. at 635-36. The psychiatrists maintained that the documents sought by the grand jury were protected from disclosure by a psychotherapist-patient privilege. Id. at 636.

2. As used in this note, the term "psychotherapist" will refer to a broad group of individuals who provide psychological services to their chents or patients, including social workers and psychiatrists as well as psychologists. Cf. S. Stone \& R. Liebman, Testimonial Privileges 385-87 (1983).

3. Although no general physician-patient privilege was recognized at common law, the states began to adopt limited statutory privileges for the psychotherapist-patient relationship in the early 1950's. See Rule 504 advisory committee note, Rules of Evidence for United States Courts and Magistrates, 56 F.R.D. 183, 242 (1973) (discussing possibility of general physician-patient privilege and probleins inherent in the privilege); Comment, Confidential Communications to a Psychotherapist: A New Testimonial Privilege, 47 Nw. U.L. Rev. 384, 385 (1952) (discussing Binder v. Ruvell, Civil Docket 52C2535 (Cir. Ct. Cook County, Ill. June 24, 1952), and calling it "the first decision of its kind without statutory support" to uphold a psychiatrist's claim of privilege; also surveying the coininon-law development of the general physician-patient privilege and advocating distinguishing it froin the psychotherapist-patient relationship).

4. Zuniga, 714 F.2d at 639.

5. See infra notes $24-25$ and accompanying text.

6. See Shuman \& Weiner, The Privilege Study: An Empirical Examination of the Psychotherapist-Patient Privilege, 760 N.C.L. REv. 893, 900-01 (1982) ("argument in favor of protecting the identity of the patient under the privilege in psychotherapy . . . has yet to be recognized by the courts"); Note, The Psychotherapist-Patient Privilege in Federal Courts, 59 NoTre DAME L. REV. 791,815 n.97 (1984) ("other courts [in addition to Zuniga] have also declined to recoguize a psychotherapist-patient privilege to protect information about the fact . . . of treatinent") (citing In re Doe, 
This note will argue, first, that federal courts should recognize a psychotherapist-patient privilege, ${ }^{7}$ and, second, that such a privilege should include protection of a patient's identity. ${ }^{8}$ No court, including those that recognize the psychotherapist-patient privilege, has ever protected a patient's identity or the dates and duration of treatment sessions. 9 Many courts, however, have justified protection of individual identity in other contexts-most notably, the identity of a journalist's confidential source, ${ }^{10}$ of an informant in a criminal prosecution, ${ }^{11}$ and of the client in an attorney-chent relationship. ${ }^{12}$ This note suggests that the rationales used by the courts in many of these cases are similarly applicable to the psychotherapist-patient situation. ${ }^{13}$

711 F.2d 1187 (2d Cir. 1983); In Re Pebsworth, 705 F.2d 261 (7th Cir. 1983); Flora v. Hamilton, 81 F.R.D. 576 (M.D.N.C. 1978); Lora v. Board of Educ., 74 F.R.D. 565 (E.D.N.Y. 1977)). But cf. infra note 9 .

7. See infra notes $30-46$ and accompanying text.

8. See infra notes $\mathbf{4 7 . 7 5}$ and accompanying text. Other commentators have reviewed the historical and legal background and the recent judicial activity in the area of the psychotlerapistpatient privilege, and argue that communications between patient and psychotherapist ought to be protected. See Note, The Psychotherapist-Patient Privilege-The Sixth Circuit Does the Decent Thing: In re Zuniga, 33 U. KAN. L. REv. 385 (1985) [hereinafter cited as Note, Privilege]; Note, supra note 6. This note, however, will focus on the more specific issue whether patient identity should come within the scope of the privilege.

9. See supra note 6 .

While some courts have been sensitive to the need to protect a psychotherapy patient's identity, see infra notes 59.74 and accompanying text, none have actually required protection of identity under Rule 501.

In Lora v. Board of Educ., 74 F.R.D. 565 (E.D.N.Y. 1977), the court's discussion of the importance of protecting a psychiatric patient's identity led to a decision to obtain rather than protect patient information. See infra notes 58-67 and accompanying text. Thus, in Lora, the court's recognition of the value of anonymity was used as a sword rather than a shield, in order for the court to allow discovery of patient files redacted as to patient identity. See Lora, 74 F.R.D. at 586-87.

Moreover, the Zuniga court, in a footnote to its holding that "as a general rule, the identity of a patient . . . does not fall within the scope of the psychotherapist-patient privilege," Zuniga, 714 F.2d at 640 , stated that "this holdimg does not mean that a court could not in its discretion or compelled by considerations of constilutional privacy . . . protect the identity of patients." Id. at 640 n.7. The court then cited the Lora decision as support for this proposition. In contrast to the reasoning of these two decisions, this note will argue that protection of identity should be evaluated as part of the psychotherapist-patient privilege, effective as a shield against discovery of such information.

10. See infra notes $85-99$ and accompanying text.

11. See infra notes 100-21 and accompauying text.

12. See infra notes $122-43$ and accompanying text.

13. The Supreme Court's proposed Federal Rules of Evidence created a federal psychotherapist-patient privilege. Rule 504, Rules of Evidence for United States Courts and Magistrates, 56 F.R.D. 183, 241 (1973). Proposed rules of the 500 series that were not adopted in the final Federal Rules of Evidence adopted by Congress, will be cited hereinafter as Proposed Rules. See infra notes 14-16 and accompanying text. 


\section{The Power of the Federal Courts to Create the Privilege aNd the Present State of the LAW}

\section{A. The Federal Rules of Evidence.}

Federal Rule of Evidence 501, in broad, sweeping terms, confers upon the federal courts the power to create evidentiary privileges by interpreting the principles of the common law "in the light of reason and experience."14 As originally submitted to Congress by the Supreme Court, article V of the Rules contained, among others, a specific rule defining a psychotherapist-patient privilege. ${ }^{15}$ The House Judiciary

\section{Rule 501 provides:}

Except as otherwise required by the Constitution of the United States or provided by Act of Congress or in rules prescribed by the Supreme Court pursuant to statutory authority, the privilege of a witness, person, government, State, or political subdivision thereof shall be governed by the principles of the common law as they inay be interpreted by the courts of the United States in the light of reason and experience. However, in civil actions and proceedings, with respect to an element of a claim or defense as to which State law supplies the rule of decision, the privilege of a witness, person, government, State, or political subdivision thereof shall be determined in accordance with State law.

FED. R. Evid. 501.

15. Proposed Rule of Evidence 504 provided:

\section{PSYChOTHERAPIST-PATIENT PRIVILEge}

(a) Definitions.

(1) A "patient" is a person who consults or is examined or interviewed by a psychotherapist.

(2) A "psychotherapist" is (A) a person authorized to practice medicine in any state or nation, or reasonably believed by the patient so to be, while engaged in the diagnosis or treatment of a mental or einotional condition including drug addiction, or (B) a person licensed or certified as a psychologist under the laws of any state or nation, while similarly engaged.

(3) A cominunication is "confidential" if not intended to be disclosed to third persons other than those present to further the interest of the patient in the consultation, examination, or interview, or persons reasonably necessary for the transinission of the communication, or persons who are participating in the diagnosis and treatment under the direction of the psychotherapist, including members of the patient's family.

(b) General Rule of Privilege. A patient has a privilege to refuse to disclose and to prevent any other person from disclosing confidential communications, inade for the purposes of diagnosis or treatment of his mental or emotional condition, including drug addiction, annong hinself, his psychotherapist, or persons who are participating in the diagnosis or treatment under the direction of the psychotherapist, including members of the patient's family.

(c) Who May Claim the Privilege. The privilege may be claimed by the patient, by his guardian or conservator, or by the personal representative of a deceased patient. The person who was the psychotherapist may claim the privilege but only on behalf of the patient. His authority to do so is presumed in the absence of evidence to the contrary.

(d) Exceptions.

(1) Proceedings for hospitalization. There is no privilege under this rule for communications relevant to an issue in proceedings to hospitalize the patient for mental illness, if the psychotherapist in the course of diagnosis or treatment has determined that the patient is in need of hospitalization.

(2) Examination by order of judge. If the judge orders an examination of the mental or enotional condition of the patient, cominunications made in the course thereof are not privileged under this rule with respect to the particular purpose for which the examination is ordered unless the judge orders otherwise.

(3) Condition an element of claim or defense. There is no privilege under this rule as to communications relevant to an issue of the inental or emotional condition of the patient in any proceeding in which he relies upon the condition as an element of his claim or 
Committee amended article V, however, by replacing the Court's specific enumerated privilege rules ${ }^{16}$ with the single rule noted above. ${ }^{17}$

The rationale for eliminating the several enumerated privileges in favor of a broad general rule is consistent with an expansive rather than a restrictive view of the role of the federal courts in recognizing evidentiary privileges. The Judiciary Committee did not intend to object to any of the specifically proposed privileges, including the psychotherapist-patient privilege. ${ }^{18}$ As Congress explained, "our action should be understood as reflecting the view that the recognition of a privilege based on a confidential relationship and other privileges should be determined on a case-bycase basis." 19

defense, or, after the patient's death, in any proceeding in which any party relies upon the condition as an element of his claim or defense.

Proposed Rule 504, 56 F.R.D. 103, 240-41 (1973).

16. The Supreine Court proposed a number of specific rules. Nine of these set forth subjects or relationships, not mentioned in the Constitution, that the federal courts were to recognize as privileged. These were Required Reports (Proposed Rule 502), Lawyer-Client (Proposed Rule 503), Psychotherapist-Patient (Proposed Rule 504), Husband-Wife, (Proposed Rule 505), Communications to Clergymen (Proposed Rule 506), Political Vote (Proposed Rule 507), Trade Secrets (Proposed Rule 508), Secrets of State and Other Official Information (Proposed Rule 509), and Identity of Informer (Proposed Rule 510). Proposed Rules 502-510, 56 F.R.D. 103, 234-58 (1973). Proposed Rule 501 provided that courts could recognize only the above privileges, "other rules adopted by the Supreme Court" and those privileges "required by the Constitution . . . or provided by Act of Congress." Proposed Rule 501, 56 F.R.D. 183, 230 (adopted in different form as FED. R. Evid. 501).

17. S. REP. No. $1277,93 d$ Cong., $2 d$ Sess. 11, reprinted in 1974 U.S. CODE Cong. \& AD. News 7051, 7058.

18. Id. at 7059 ("It should be clearly understood that, in approving this general rule as to privileges, the action of Congress should not be understood as disapproving any recognition of a psychiatrist-patient, or husband-wife or any other of the enunerated privileges contained in the Supreme Court rules."). Moreover, Rule 504 was adjudged an appropriate guide and standard for applying Rule 501 to the psychotherapist-patient privilege. Lora v. Board of Educ., 74 F.R.D. 565, 569 (E.D.N.Y. 1977).

19. S. REP. No. 1277, supra note 17,1974 U.S. CODE CONG. \& AD. NEwS at 7059.

The second part of Rule 501 indicates that federal common law should govern the recognition of privileges in federal question and crimmal cases, and that in civil actions and proceedings goverued by Erie R.R. v. Tompkins, 304 U.S. 64 (1938), state privilege law should apply. FED. R. Evid. 501.

The language of this part of the rule was the subject of intense debate. Some Senators feared that the language of the rule would create serious difficulty, because state law would apply if the issue were an element of a state claim or defense, but not if it were a mere "step along the way in the proof of it." S. REP. No. 1277, supra note 17, 1974 U.S. CODE CONG. \& AD. NEwS at 7058. In the opinion of the Senate coinmittee, "[t]he question of what is an element of a claim or defense is likely to engender considerable hitigation." Id. The Senate suggested an alternative, which provided:

[I]n crininal and Federal question civil cases, federally evolved rules on privilege should apply since it is Federal policy which is being enforced. Conversely, in diversity cases where the litigation in question turns on a substantive question of state law, . . . State rules of privilege should apply unless the proof is directed at a claim or defense for which Federal law supplies the rule of decision (a situation which would not commonly arise).

Id. at 7059. The Conference Report, however, inust be presuned definitive on the question of congressional intent as to the interpretation of the Rule's language. Thus, this note presumes that (1) in all federal question and criminal cases, federal privilege law will apply, (2) in diversity cases "where 


\section{B. The Psychotherapist-Patient Privilege in the Federal Courts.}

Judicial recognition of any federal evidentiary privilege depends upon a careful balancing process. "The relationship in question and its underlying values must be thought more important than the accurate outcome of judicial proceedings, and the absence of the privilege must threaten to destroy the relationship and its underlying values."20 $\mathrm{Be}$ cause of the unique character of psychotherapy, a psychotherapist generally cannot successfully treat a patient unless he can assure the patient of complete confidentiahty. ${ }^{21}$ Consequently, in order to safeguard the therapy relationship, a privilege to withhold therapy-related evidence from a judicial proceeding is necessary. ${ }^{22}$

Although the federal courts have recognized the unique nature of the psychotherapist-patient relationship, ${ }^{23}$ they have failed to reach a

a claim or defense is based upon federal law, . . federal privilege law will apply to evidence relevant to the federal claim or defense," and (3) in other diversity cases, state privilege law will apply. See H.R. CONF. REP. No. 1597, 93d Cong., 2d Sess. 7, reprinted in 1974 U.S. CODE CONG. \& AD. News 7098, 7100-01 (citing Sola Elec. Co. v. Jefferson Elec. Co., 317 U.S. 173 (1942)).

20. Shuman \& Weiner, supra note 6 , at 893-94. Because all evidentiary privileges withhold potentially dispositive evidence from the judicial process, "they must be strictly construed." Trammel v. United States, 445 U.S. 40, 50 (1979). The policy involved has been clearly stated by the Supreme Court on several occasions. See, e.g., Elkins v. United States, 364 U.S. 206, 234 (1959) ("The pertinent general principle, responding to the decpest needs of society, is that society is entitled to every man's evidence."); United States v. Bryan, 339 U.S. 323, 331 (1950) ("Certain exemptions from attending or, having attended, giving testimony are recognized by all courts. But every such exemption is grounded in a substantial individual interest which has been found . . . to outweigh the public interest in the search for truth.") (emphasis added).

In Elkins the Supreme Court acknowledged that the primary role of the court is to serve justice, and in doing so, "the enforcement of basic moralities by courts should at times be deemed more important than the full utilizatiou of all relevant evidence in a particular case." Elkins, 364 U.S. at 234-35. Thus, the Court has demonstrated a concern for individual protection, even at the cost of some relevant evidence.

21. R. Slovenko, Psychotherapy, Confidentiality and Privileged Communication 50 (1966) (quoting 4 GROUP FOR THE ADVANCEMENT OF PSYCHIATRY, REPORTS AND SYMPOSIUMS, REPORT No. 45, at 111 (1960) [hereinafter cited as GAP REPORT No. 45]).

22. The proponents of the privilege firmly believe "that the social value which effective psychiatric treatment has for the community far outweighs the potential loss of evidence resulting from the withholding of testimony by a psychiatrist about his patient." Id.

23. One court has adopted verbatim the views advanced in a scholarly treatise:

The psychiatric patient confides more utterly than anyone else in the world. He exposes to the therapist not only what his words direetly express; he lays bare his entire self, his dreams, his fantasies, his sins, and his shame. Most patients who undergo psychotherapy know that this is what will be expected of them, aud that they cannot get help except on that condition. ... It would be too much to expect them to do so if they knew that all they say-and all that the psychiatrist learns from what they say-may be revealed to the whole world from a witness stand.

Taylor v. United States, 222 F.2d 398, 401 (D.C. Cir. 1955) (quoting M. GUTTMACHER AND H. Wethofen, PSYCHIATRY AND THE LAW 272 (1952)).

Another rationale for the psychotherapist-patient privilege was cited by the Zuniga court: Among physicians, the psychiatrist has a special need to maintain confidentiality. His capacity to help his patients is completely dependent upon their willingness and ability to talk 
consensus on whether the privilege merits judicial recognition. ${ }^{24}$ Two obstacles inhibit the proper disposition of many psychotherapist-patient privilege cases by the federal courts. First, courts continue to equate the psychotherapist-patient relationship with the physician-patient relationship, ignoring the special circumstances of the patient undergoing psychotherapy. ${ }^{25}$ In re Zuniga demonstrates the second common error by upholding the existence of the privilege, ${ }^{26}$ yet failing to realize that the

freely. This makes it difficult if not impossible for him to function without being able to assure his patients of confidentiality and, indeed, privileged communication. . . . [While] there may be exceptions to this general rule . . . , there is wide agreement that confidentiality is a sine qua non for successful psychiatric treatment. The relationship may well be likened to that of the priest-penitent or the lawyer-chent. Psychiatrists not only explore the very depths of their patients' conscious, but their unconscious feelings and attitudes as well. Therapeutic effectiveness necessitates goiug beyond a patient's awareness and, in order to do this, it must be possible to communicate freely. A threat to secrecy blocks suecessful treatment.

Zuniga, 714 F.2d at 638 (quoting GAP REPORT No. 45, supra note 21, at 92) (footnotes omitted) quoted in Proposed Rule 504 advisory committee note, 56 F.R.D. 183, 242 (1973). See also U.S. v. Layton, 40 F.R.D. 520, 526 (N.D. Cal. 1981) (federal courts have recognized that psychotherapy "will usually be seriously jeopardized by the lack of any guarantee of confidentiality").

24. Compare United States v. Lindstrom, 698 F.2d 1154, 1167 (11th Cir. 1983) (recognizing general validity of patient's privacy interest in confidentiality of medical records and society's interest in encouraging free flow of information between patient and psychotherapist, but holding that these interests "must "yield to the paramount right of the defense to cross examine effectively the witness in a criminal case" ") (quoting United States v. Soc'y of Ind. Gasoline Marketers, 624 F.2d 461, 469 (4th Cir. 1979)); Ramer v. United States, 411 F.2d 30, 39-40 (9th Cir.) (privilege may exist when a psychiatrist treats a patient, but not when the psychiatrist examines a person in order to testify about his condition), cert. denied, 396 U.S. 965 (1969); and Flora v. Hamilton, 81 F.R.D. 576, 579-80 (M.D.N.C. 1978) (recognizing policies behind psycliotherapist-patient privilege, but ruling that plaintiff who put at issue his ability to work was compelled, for effective discovery, to allow inspection of his army medieal file) with United States v. Meagher, 531 F.2d 752, 753 (5th Cir.) (flatly rejecting the privilege), cert. denied, 429 U.S. 853 (1976); United States v. Witt, 542 F. Supp. 696, 698-99 (S.D.N.Y.) (refusing to recognize the privilege and noting that even if psycliotlierapistpatient privilege is theoretically plausible, right to invoke it is "not absolute"), aff"d, $697 \mathrm{~F} .2 \mathrm{~d} 301$ (2d Cir. 1982); and United States v. Brown, 479 F. Supp. 1247, 1253 (D. Md. 1979) (holding that "[n]o general psychiatrist-patient privilege is available to bar the production of documents under the Federal Rules of Evidence"). See also Taylor v. United States, 222 F.2d 398 (D.C. Cir. 1955) (interpreting D.C. statute granting psychotherapist-patient privilege). In United States v. Layton, 90 F.R.D. 520, 525 (N.D. Cal. 1981), the court asserted that federal courts have universally stated that no psychotherapist-patient privilege existed at common law and that, therefore, it does not exist in the federal courts. The Layton court mentioned, however, that federal courts have recognized that the decision to see a psychiatrist falls within a "cluster of constitutionally protected choices." Id. at 526.

25. "In both Lindstrom and Meagher, in which the Eleventh and Fifth Circuits refused to aecept the privilege, the courts simply equated [the psychotherapist-patient privilege] with the physician-patient privilege without analyzing the unique aspects of the psychotherapist-patient relationship." Zuniga, 714 F.2d at 638.

26. The Zuniga court "recognized the compelling necessity for the privilege," $i d$. at 639 , but concluded that this did not justify extendiug the scope of the privilege to prevent disclosure of patient identity, id. at 640 . 
mere fact that a patient is receiving psychotherapy is also confidential. ${ }^{27}$ The Zuniga court did, however, express the proper approach: "Just as the recognition of privileges must be undertaken on a case-by-case basis, so too must the scope of the privilege be considered."28

\section{The Psychotherapist-Patient Privilege}

Because no doctor-patient privilege existed at common law, ${ }^{29}$ courts that fail to distinguish the psychotherapist-patient relationship from the traditional doctor-patient relationship automatically refuse to recognize a psychotherapist-patient privilege. When the psychotherapist-patient relationship is examined, however, it becomes clear that the relationship fully satisfies the requirements for a federal evidentiary privilege.

Federal courts have cited with approval Dean Wigmore's four fundamental conditions necessary to establish any privilege:

(1) The communications must originate in a confidence that they will not be disclosed.

(2) This elenient of confidentiality must be essential to the full and satisfactory inaintenance of the relation between the parties.

(3) The relation inust be one which in the opinion of the community ought to be sedulously fostered.

(4) The injury that would inure to the relation by the disclosure of the communications nust be greater than the benefit thereby gained for the correct disposal of hitigation. ${ }^{30}$

Wigniore maintams that "[a] negative answer to any one of these [criteria] would leave the privilege without support." 31 In applying this standard to the physician-patient relationship, the federal courts agree that the harm done to the litigation process by withholding information generally outweighs the injury done to the relationship, because that relationship does not depend upon secrecy. ${ }^{32}$

27. Slovenko, Psychiatry and a Second Look at the Medical Privilege, 6 WAYNE L. REv. 175, 188 (1960) ("It is vital to maintain confidentiality as to the fact of treatment as well as to communications made in treatment."); see infra notes 53-56 and accompanying text.

28. Zuniga, 714 F.2d at 639 (citing Upjohn Co. v. United States, 449 U.S. 383, 396-97 (1981)).

29. E.g., United States v. Williams, 337 F. Supp. 1114, 1115 (S.D.N.Y. 1971).

30. $8 \mathrm{~J}$. Wigmore, Evidence in Trials at CoMmON LAW $\S 2285$ (McNaughton rev. ed. 1961) (emphasis in original).

31. Id., $\$ 2380 \mathrm{a}$, at 829 . Wigmore was a "vigorous opponent of the physician-patient privilege." Rappeport, Psychiatrist-Patient Privilege, 23 MD. L. REv. 39, 48 (1963).

32. See, e.g., United States v. Kansas City Lutheran Home \& Hosp. Ass'n, 297 F. Supp. 239, 243-44 (W.D. Mo. 1969) (quoting 8 J. Wigmore, supra note 30, $\S 2380$ a, at 831-32). The Kansas City court stated:

It is certain that the practical employment of the privilege has come to inean little but the suppression of useful truth-truth which ought to be disclosed and would never be suppressed for the sake of any inherent repugnancy in the medical facts involved. Ninetynine percent of the litigation in which the privilege is invoked consists of three classes of cases-actions on policies of life insurance where the deceased's misrepresentations of his health are involved, actions for corporal injuries where the extent of the plaintiffs injury is 
The need for the psychotherapist-patient privilege, however, is distinguishable from the need that arises from the traditional physician-patient situation. The Supreme Court recognized the important differences between the two relationships by including the psychotherapist-patient privilege in its proposed Federal Rules of Evidence ${ }^{33}$ while denying privileged status to the physician-patient relationship. Moreover, several commentators have suggested that the psychotherapist-patient situation is more analogous to the priest-penitent relationship than to the doctorpatient relationship. ${ }^{34}$ Both psychiatry and religion are founded on the elements of "concern, sensible involvement, sympathy, and a respect for the dignity of the individual."3s As in the practice of confession, "psychotlierapy by its very nature is worthless unless the patient feels assured from the outset that whatever he may say will be forever kept confidential."36

Though federal courts have held that the physician-patient relationship fails to meet Wigniore's standard, ${ }^{37}$ several commentators have indicated that Wigniore's four prerequisites are satisfied in the case of the

at issue, and testamentary actions where the testator's mental capacity is disputed. In all of these the medical testimony is absolutely needed for the purpose of learning the truth. In none of them is there any reason for the party to conceal the facts, except as a tactical maneuver in litigation. . . . In none of these cases need there be any fear that the absence of the privilege will subjectively hinder people from consulting physicians freely. The actually injured person would still seek medical aid, the honest insured would still submit to medical examination, and the testator would still summon physicians to his cure.

Id. (emphasis added). See also United States v. Mancuso, 444 F.2d 691, 695 (5th Cir. 1971) (physician-patient privilege depends on statute and does not exist at common law); Barnes v. United States, 374 F.2d 126, 128 (5th Cir.) (because existence of privilege depends on statute, if no such statute exists in court's jurisdiction, physician-patient privilege is not available), cert. denied, 389 U.S. 917 (1967).

33. A specific psychotherapist-patient privilege was set forth in Proposed Rule 504, 56 F.R.D. 183, 240-41 (1973). See supra note 13.

34. C. Dewitt, Privileged Communication Between Physician and Patient 88 n. 8 (1958) (quoting Coniment, supra note 3, at 386). Wigmore concluded that the priest-penitent relationship neets the four criteria and is therefore entitled to enjoy the testimonial privilege. First, permanent secrecy is essential to religious confession. Second, penitential confessions would cease if they were subject to disclosure in court. Third, the penitential relationship is worth fostering, and fourth, the injury to the penitential relationship by disclosure is significant while "the gain [to justice] would be merely the party's own confession . . . [which] ought in no system of law to be relied upon as a chief material object of proof." $8 \mathrm{~J}$. WIGMORE, supra note $30, \S 2396$, at 878.

35. R. SLOVENKo, supra note 21 , at 39 (quoting I. EWALT \& D. FARNSWORTH, TEXTBOOK OF PSYCHIATRY 300 (1963)).

36. Comment, supra note 3 , at 386.

Without a promise of secrecy from the therapist, buttressed by a legal privilege, a patient would not be prone to reveal personal data which he fears might evoke social disap. proval. Not only is such data essential for the purpose of constructing a reliable case history, but also the catharsis achieved by its verbalization may itself be a significant factor in treatment.

Id. at 386-87.

37. See supra note 32. 
relationship between psychotherapist and patient. ${ }^{38}$ First, communications from a patient to a psychotherapist do originate in the expectation of confidentiality. Psychiatric patients divulge to their therapists secret thoughts and emotions that they would not reveal even to their families or close friends. ${ }^{39}$ Communications that are made during therapy may reveal unattractive and antisocial tendencies of the patient; thus psychotherapy patients expect and demand confidentiahty in return for their open disclosure. 40

Second, this element of confidentiality is essential to a complete and satisfactory relationship between the parties. In order for treatment to be successful, patients must be able to commumicate their thoughts and emotions freely and fully, even when such thoughts are abhorrent to society. ${ }^{41}$ If patients suspect disclosure of their confidences, they will hesitate to consult a psychotherapist and may forego needed treatment. ${ }^{42}$ Emotional and social problems, if untreated, are detrimental to both the mdividual and society. ${ }^{43}$ Thus, as evidenced by the popularity and respect psychotherapy has gamed as a science, Wigmore's third condition is satisfied, because the psychotherapist-patient relationship is one that the community considers worth fostering. ${ }^{44}$

Finally, the injury to the psychotherapist-patient relationship from disclosing confidential communications far outweighs the incremental benefit such communications can provide as courtroom evidence. ${ }^{45}$ Most of the inforination communicated to psychotherapists is not factual; rather, it is an abstract expression of the patient's mner feelings and emotions. These impressions lack accuracy, are often speculative, and are not necessarily sincere, rendering them "irrelevant and immaterial evidence." 46 The required balance tilts in favor of protecting the confidenti-

38. See Slovenko, supra note 27 , at $184-95$ (explaining in detail how each of four criteria is met); Cominent, supra note 3, at 387 (similar, but with less extensive discussion of Wigmore's four criteria). But cf. Shuman \& Weiner, supra note 6, at 900-04 (describing some probleins with the privilege's theoretical justifications).

39. See Slovenko, supra note 27 , at 185 .

40. Id. at $186-88$.

41. Id. at $186-87$.

42. Id. at $185-87$.

43. See Smith, Constitutional Privacy in Psychotherapy, 49 GEo. WASH. L. REv. 1 (1980):

The societal interest in protecting the confidentiality of therapy is to promote einotional and mental health, which uitimately will reduce antisocial activity and other societal burdens that result froin untreated or poorly treated inental problems. Successful psychotherapy may reduce social problems such as juvenile delinquency, marital complications, and violent crime. It inay also reduce the cost of caring for dependents of the mentally ill and increase the productivity of those with mental deficiencies or difficulties.

Id. at 39 .

44. See Slovenko, supra note 27 , at 192.

45. Id.

46. Id. at 194. 
ality of such disclosures because they are of dubious value at trial, and of paramount value to successful psycliatric treatment.

\section{Protection of Patient Identity}

In re Zuniga demonstrates the uniform reluctance of the federal courts to extend the scope of the psychotherapist-patient privilege to include protection of patient identity. ${ }^{47}$ After balancing the interests protected by allowing the evidence to be withheld witl those advanced by disclosure, ${ }^{48}$ the Zuniga court held that, as a general rule, information as to the identity of a psychotherapist's patients-the patients' names, the dates on whicl they were treated, and the lengtll of treatment on each date-does not fall within the scope of the psychotherapist-patient privilege. ${ }^{49}$ The court observed that "[t]he essential element of the psychotherapist-patient privilege is its assurance ... that [the patient's] innermost thoughts may be revealed without fear of disclosure" and that "[m]ere disclosure of the patient's identity does not negate this element." 50 This interpretation of the privilege's scope fails to consider that in today's society many people desire and expect to inaintain secrecy as to the fact that they are receiving psychiatric treatment.

While the Zuniga court was correct in recognizing a psychotherapist-patient privilege, the court failed to distinguish completely the psychotherapist-patient froin the plysician-patient relationship when it refused to extend the scope of the privilege to mclude protection of patient identity. ${ }^{51}$ Federal courts interpretimg state physician-patient privilege statutes note that the physician-patient privilege extends only to communications, and not to the existence of the relationship. ${ }^{52}$ It is in-

47. See supra notes 23-28 and accompanying text.

48. The Supreme Court of the United States has held that recognition of federal evidentiary privileges should occur on a case-by-case basis, see Umited States v. Gillock, 445 U.S. 360, 367 (1980); Trammel, 445 U.S. 40, 47 (1980), and that the scope of such privileges should therefore be determined in the same way. See Upjohn Co. v. United States, 449 U.S. 383, 396-97 (1981).

49. Zuniga, 714 F.2d at 640.

50. Id.

51. Although the court recognized the distinction in determining whether the psychotherapistpatient privilege existed, id. at 638-39, it inexplicably blurred the distinction in determining the scope of the privilege, $i d$. at 640 .

52. See Ranger, Inc. v. Equitable Life Assurance Soc'y, 196 F.2d 968, 973 (6th Cir. 1952) (under Michigan law, testimony by physician about date of attendance is not privileged); Simpson v. Braider, 104 F.R.D. 512, 523 (D.D.C. 1985) ("[N]ames of therapists, dates of visits and general purpose of treatment do not fall within the physician-patient privilege . . . ."); Shuman \& Weiner, supra note 6, at 900 ("[T] he physician-patient privilege has not been construed . . . to protect against disclosure of an individual's status as a patient unless to do so would reveal the substance of the communication . . . ."); Slovenko, supra note 27, at $188 \mathrm{n.46}$ ("[T]he fact of the physicianpatient relationship, that the person was under treatment, the number of visits, and the duration of treatment, are not privileged areas."). 
appropriate, however, for courts to treat the psychotherapist-patient privilege in a similar manner. In order to encourage people to seek needed psychiatric help, the mere existence of the relationship must remain confidential.53 A powerful social stigma is often associated with psychiatric treatınent. ${ }^{54}$ For example, there is evidence that people

53. See R. SLoVENko, supra note 21 , at 43. ("[W] ithout assurance of confidentiality, a person would even hesitate to contact a psychiatrist, much less to enter into a meaningful therapeutic relationship with him.").

54. The social stigma suffered by patients of psychotherapy when the fact of their treatment is revealed is well documented. See Slovenko, Accountability and Abuse of Psychiatric Confidentiality, 2 INT'L J.L. \& Psychiatry 431, 433, 438 (1979) ("Many psychiatric patients fear that they will become objects of stigma, censure and ridicule if even disclosure of the [therapy] relationship is made.") [hereinafter cited as Slovenko, Accountability]; id. at 442-43 ("Often, one of the most intimate secrets of a psychiatric patient is that he or she is a psychiatric patient."); see also AMERICAN Psychiatric Ass'N, Confidentialiry and Third Parties, TAsk Force Report 9, at iv (June 1975) (" $[T]$ he mere disclosure of the fact of psychiatric treatment is sometimes felt to be a hazard to the patient.").

It has been said that "a person sees a psychiatrist, by and large, with the same secrecy that a man goes to a bawdy house." Slovenko, Accountability, supra, at 453 (citing Slovenko, supra note 27, at 188 n.46). One member of President Carter's Commission on Mental Health, a former mental patient, stated at the Commission's first meeting:

I am half im the closet and half out. I am a former patient, and I intended to have everyone on the Commission know that; but I did not want to announce it to the United States of America. I have becn all over the United States . . . talking about mental health issues and about patients' rights issues. But the people in the place where I live do not know, most of them, that I am a former patient. I didn't tell the nranager this when I filled out the form. When I told him later, he said he was glad he hadn't known because he would not have let me in.

Carter, Removing the Mental-Illness Stigma, N.Y. Times, Nov. 18, 1977, at A31, col. 1. The article reporting this statement, written by the honorary chairman of the Commission, Rosalynn Carter, refers to testimony heard by the Commission "from several hundred professionals and lay persons about the pain and the barriers facing mental patients in their own communities." Id. These "barriers" include people's reluctance to hive near patients and former patients because they fear crime, danger to their children, and reduced property values; zoning laws that exclude former mental patients; difficulties with job security and advancement; and the fact that many people consider need for psychiatric care a disgrace. Id. "In sum, meutal illness is still not aceeptable in our society." Id. Slovenko finds that the stigma attaches to the mere fact of receiving treatment: "By and large, people in the community, even those who are well-informed on other matters, consider a person's treatment by a psychiatrist as evidence of his 'queerness' or even insanity." Slovenko, supra note 27, at 188. But see Shuman \& Weiner, supra note 6, at 902 (some people in analysis seem to view treatment as a status symbol).

The social stigma suffered by the psychotherapy patient who is or has been hospitalized is the subject of a great deal of documentation. Medical professionals note that "much of the public attitude toward hospitalization is based on prejudice, [and] fear of social stigma . . . [T] he patient feels more an object of shame . . the longer he remains hospitalized." Gralnick \& Duncan, Problems of the Patient in Transit from Hospital to Community, in MeNTal Patients IN TransiTION 27 (M. Greenblatt, D. Levinson \& G. Klerman eds. 1961). Because a patient "may see himself as a shameful person[,] . . . the patient may make every effort to deny his sickness not because he does not want help, but because he does not want to be rejected." Id. at 28.

When alleged patient abuse and insurance fraud were investigated at Chicago Lakeshore Hospital, the patients feared "the effects of their hospitalization being made public." Zielenziger, Nothing Sacred in Chicago, Including Medical Records, New Times, Oct. 28, 1977, at 12, col. 1. One patient said, "It would jeopardize my job, no doubt about it . . . . The very fact of my having been in a 
choose to pay for psychotherapy out of their own pockets rather than risk disclosure of psychiatric treatment by filing insurance claims with employers. ${ }^{55}$ The stigma that accompanies such disclosure can be particularly severe and damaging to pohticians, high-level corporate executives, and other public figures. ${ }^{56}$ As a result, a "person may hesitate to

psychiatric hospital would tend to make people assume that there would be an element of instability." Id. Another patient said, "If my name ever came out without my consent . . . I would never-never-go back into a hospital, even if I had another breakdown. I would die first." Id.

55. Sobel, Thousands with Mental Health Insurance Choose to Pay Own Bill, N.Y. Times, Aug. 4, 1981, at C1, col. 1. This article cites Dr. Steven Sharfstein, associate director for behavioral medicine at the National Institute for Mental Health, who estimates that about $15 \%$ of all adults who have employer-provided mental health insurance waive reimbursement in order to conceal the fact that they receive treatment. Dr. Sharfstein did not attempt to determine "the number of insured employees who forego treatment rather than let their employers know" that they receive psychotherapy. Id. The article also refers to a poll of psychiatric patients that was conducted by Dr. Douglas A. Sargent, a member of the American Psychiatric Association's Committee on Confidentiality, to determine "whether the supposed stigma of psychotherapy has kept them from collecting insurance benefits." Id. One patient responded: "I can remember cringing . . . when I realized that if I took the job I had sought, I would have to turn in my medical bills to the personnel manager, to be forwarded to the insurance company. Instead, I took another job without this requirement." Id. A 20 year-old college student paid cash despite financial difficulty, because of her ambitions for a political career. Id.

56. "In the case of very important persons, the inere fact of seeing a psychiatrist may permanently damage a career." Slovenko \& Grossman, Confidentiality and Testimonial Privilege, in 3 Psychiatry ch. 31, at 6 (J. Cavenar ed. 1985). For discussion of the effect of mental illness upon celebrated public figures and the difficulties of administering treatnent, see 8 GROUP FOR THE ADVANCEMENT of Psychiatry, The VIP with Psychiatric IMPAIRMENT, Report No. 83, at 15394 (1973) (discussing lack of effective procedures for dealing with the special situation of emotional illness of public figures). The report notes that "[p]ersons in public life are often reluctant or unwilling to seek help from a psychiatrist . . . because they know that if this becomes known, they will be jeopardizing their careers or shaking the confidence of their public in their decisions and their leadership." Id. at 183. "Through fear of loss of status and position, and for other reasons as well, many VIPs conceal their identity while under treatment." Id. at 185 . In addition, "[c]ompleting a successful treatment program does not necessarily bring an end to the problems of dealing with the VIP patient . . . . The very fact that a person has undergone psychiatric care is still stigmatizing in many quarters." $I d$. at 186 . In sum, "[p]ublic knowledge of psychiatric inquiry is currently considered the kiss of death to a high-level official." Id. at 187.

An interesting account in the New York Times Magazine focused on the particular difficulties and hazards for influential individuals seeking psychotherapy in Washington, D.C. See McElwaine, On the Couch in the Capital, N.Y. Tines, May 22, 1983 (Magazine), at 58. This article refers to the experience of Senator Thomas F. Eagleton, who was dropped as George McGovern's vice-presidential running mate in 1972, upon confirming "that he had been hospitalized and received electric shock treatment [in the 1960's] for nervous exhaustion and depression." Id. at 60. Disclosure of Eagleton's psychiatric treatment rendered him a political liability for McGovern. Id.

In general, politicians fear admitting they receive psychotherapy because of the effect it might have on voter confidence. Id. Sinilarly, lawyers fear losing their clients, and journalists fear losing their credibility with their readers. Id. Consequently, McElwaine concludes, many powerful individuals do their utmost to conceal the fact that they see psychotherapists. Id.

A fairly recent plan by the majority leader of the Minnesota Senate to hire a psychiatrist to be available to members and legislative employees failed miserably in light of "shrink" jokes aimed at the legislators and negative letters to local newspapers. See Plan Dropped to Hire Psychiatrist for Minnesota Senate, N.Y. Tines, Feb. 4, 1980, at B2, col. 5. The counseling was intended to be 
visit a psychiatrist out of fear that he will be set apart from his fellow man." 57

Few commentators have argued in favor of protecting a patient's identity under the psychotherapist-patient privilege, and no court has adopted such position. ${ }^{58}$ At least two federal courts, however, have given favorable consideration to the underlying rationales for protecting patient identity. In Lora v. Board of Education, ${ }^{59}$ a federal district court in New York discussed both the theory of a constitutional right to privacy $^{60}$ and the psychotherapist-patient privilege in adjudicating a claim

available for problems that might affect a legislator's work, such as "alcoholism, insomnia and family difficulties." Id. After the plan failed, the majority leader was quoted as saying: "If we hire anybody . . . it will be a preacher or a shepherd." Id. Indeed, counselling by clergy has been deemed to create less social stigma than medically provided psychotherapy. See Barden, Ministering to Emotions As Well as to the Spirit, N.Y. Times, Sept. 28, 1980, at 66, col. 1 (quoting Rev. Franklin E. Vilas, Jr., of the President's Commission on Mental Hcalth: "Many are more willing to go into counseling connnected to the church because of a certain stigma attached to psychotherapy.").

In sum, for lay people and public figures alike, " mental illness . . . is the 'loathsome disease.' Surveys indicate that the general public regards a person seeing a psychiatrist with fear, distrust or dislike. The public generally feels or acts differently toward a psychiatric patient." Slovenko, $A c$ countability, supra note 54, at 451 . "It is sad, but nevertheless true, that there is still considerable stigma in receiving mental health services." Id. (quoting letter from Sen. Daniel K. Inouye to Dr. Mark Stern (date omitted), reprinted in 14 VoICES/J. AM. ACAD. PsYCHOTHERAPISTS 76, 76 (1979)).

57. Slovenko, supra note 27 , at 188 .

58. See Comment, supra note 3 , at 387 (erroneously applying the rules of the physician-patient relationship and concluding that mere fact of consultation or dates or number of consultations is not within the scope of the psychotherapist-patient privilege); supra note 6 and accompanying text.

59. 74 F.R.D. 565 (E.D.N.Y. 1977).

60. The constitutional right to privacy, as an alternative theory of confidentiality, will not be extensively discussed in this note. Nevertheless, it is important to note that when constitutional privacy rights are involved, they strengthen the case for the privilege claim. See id. at 570 ("Such a [constitutional privacy] clain is particularly conpelling when the material to be disclosed includes communications by a patient to a psychotherapist."). In Lora, the plaintiffs alleged a violation of "[t]wo distinct but related personal privacy interests." Id. The first was the right to have intimate and embarrassing details proteeted from public exposure; the second was the right to make independent choices about things "that may seriously [a]ffect [one's] personal physical or inental health-specifically, the right to be free to seek benefit from psychotherapeutic counseling." Id. For a fuller treatment of the constitutional right to privacy as the basis for the psychotherapist-patient privilege, see Sinith, supra note 43 , at 1-45.

Privacy rights are not the only possible constitutional foundation for protection of a psychotherapy patient's identity. Identity has been protected in the federal courts on the ground of freedon of association. The Supreme Court has held in two landinark cases-NAACP v. Alabama, 357 U.S. 449 (1958), and Bates v. City of Little Rock, 361 U.S. 516 (1960)-that a court can deny requests for disclosure of an individual's identity if such disclosure would deter the exercise of the individual's freedoin of association under the first and fourteenth amendments. Both of these decisions, however, used the freedom of association as a basis for protecting identity in the context of political association.

In $N A A C P$ v. Alabama, the Court recognized that the right to associate privately is an inherent part of one's freedom of association. Alabama, 357 U.S. at 462. The Court addressed the question "whether Alabama, consistently with the Due Process Clause of the Fourteenth Amendment, [could] compel petitioner to reveal to the State's Attoruey General the names and addresses of all its 
that a school district applied arbitrary and racially discriminatory standards "for identification, evaluation, and educational placement of emotionally handicapped children."61

Lora concerned a motion to produce documents; the records sought were several randomly selected, anonymous diagnostic and evaluation files. ${ }^{62}$ In permitting discovery of the redacted files, the court based its analysis on the assertion that, $\mathrm{m}$ the case of psychotherapy, "it is identity, rather than anonymous commumications, that patients generally wish to have shielded from exposure."63

Consistent with the case-by-case approach of recognizing and analyzing privileges under Rule 501, the Lora court conducted a careful balancing of the public ${ }^{64}$ and private interests involved.65 While it

Alabama members and agents, without regard to their positions or functions in the Association." Id. at 451. The NAACP opposed disclosure of the identities of the group's ordinary "rank-and-file members," because it feared unfavorable reprisals. Id. at 462-63. The group informed the Court of the effect that sueh disclosure had had on individuals in the past: "[R]evelation of the identity of . . . [such] rank-and-file members has exposed these members to economic reprisal, loss of employment, threat of physical coercion, and other manifestations of public hostility." Id. at 462 . The Court held that compelling this disclosure of the identity of individuals involved in advocacy (particularly of dissident or controversial views) might indeed infringe on their constitutional right to associate freely. Moreover, compelled disclosure might cause members to withdraw from the group and might deter others from becommg affiliated, because they would anticipate negative consequences. Id. at 462-63. See also Bates v. City of Little Rock, 361 U.S. 516, 523-24 (1960) (similar to Alabama; to require disclosure of the members' identities "would work a significant interference with the freedom of association of [the NAACP's] members").

The Supreme Court has thus recognized the right to maintain anonymity with regard to association with political organizations aimed at advancing minority rights. Federal courts, however, have failed to recognize a similar need to maintain anonymity as to individuals' associations with psychotherapists and psychotherapy undertaken for the purpose of improving individual mental health. Just as members of the NAACP may fear harassment and harm from exposure of their affiliation, psychiatric patients may fear embarrassment and stigmatization if their association with psychotherapists or mental treatment is publicly disclosed. See generally Smith, supra note 43, at 21-27 (discussing "autonomy privacy," i.e., the right to seek privately the benefits of psychotherapy, as distinct from "information privacy," which concerns confidentiality of communications in therapy). The right to pursue the benefits of psychiatric trcatment should include the right to pursue them anonymously. In the scenarios typified by Alabama and Bates, the federal courts weigh the state's need to compel disclosure of an association's membership against the individual's freedom to associate anonymously. It follows that these courts should also weigh the competing interests that are implicated when the identity of a psychiatric patient is in issue. As mandated by Federal Rule of Evidence 501, the federal courts must undertake this analysis on a case-by-case basis; by using the in camera hearings that are used in analogous situations, they can investigate these competing interests in a nonpublic setting. See infra note 113 and accompanying text.

61. Lora, 74 F.R.D. at 568.

62. Id. at 567 .

63. Id. at 586-87 (emphasis added).

64. "Of all the factors in the balancing equation, the most constant is the need for full development of the facts in federal litigation im order that the paramount public interest in the fair administration of justice be served." Id. at 578; see also FED. R. EVID. 102 ("These rules shall be construed to secure fairness in administration, elimination of unjustifiable expense and delay, and promotion of 
permitted discovery of the files, the court conditioned their availability on complete redaction and codification as to patient identity. ${ }^{66}$ The premise of the Lora decision is that, to both the psychotherapist ${ }^{67}$ and the patient, ${ }^{68}$ protection of identity is the crucial element of the psychotherapist-patient relationship.

In In re Pebsworth, ${ }^{69}$ the United States Court of Appeals for the Seventh Circuit recognized the importance of protecting patient identity in the course of the psychotherapist-patient relationship. Pebsworth, like Zuniga, involved a psychotherapist's challenge to a grand jury subpoena in connection with an investigation of alleged billing fraud..$^{70}$ The subpoena required records that included patient names, dates of treatnent, and some patients' diagnoses. ${ }^{71}$ Reasoning that the patient had waived the psychotherapist-patient privilege by filing nisurance reimbursement claims, ${ }^{72}$ the court of appeals ordered production of the records for the

growth and development of the law of evidence to the end that the truth may be ascertained and proceedings justly determined.").

65. Four factors were considered in determining whether disclosure of identity would interfere with the plaintiffs privilege expectations:

First, is the identification of the individuals required for effective use of the data? Second,

is the invasion of privacy and risk of psychological harm being limited to the narrowest possible extent? Third, will the data be supplied only to qualified personnel under strict controls over confidentiahity? Fourth, is the data necessary or simply desirable?

Lora, 74 F.R.D. at 579.

66. Id. at 586-87.

67. Both the Lora court and various commentators have emphasized the day-to-day efforts of psychotherapists to maintain the confidentiality of patient identity. See id. at 581-82. According to Slovenko, psychotherapists' efforts to preserve confidentiality are not motivated simply by fear of defamation or invasion of privacy actions by a patient. Rather, the profession must assure patients complete confidentiality in order to preserve public trust. Slovenko, supra note 27, at 188.

Psychotherapists maintain their own financial and bnsmess records im a manner that conceals the identity of the particular patient in therapy. Psychotherapists discuss their fees with patients at the beginning of the relationship to avoid using bill-collecting agencies, id. at 188-89, and "[q]uite frequently, patients are recorded by number in the [psychotherapists'] ledger so that their names will not be known to accountants or internal revenue agents." Id. at 189. Furthermore, when publishing scientific data, "[psychotherapists] disguise their clinical data to avoid the recognition of the patient, often to the detriment of the scientific value of the material." Id. In contrast, in scientific writing and teaching, physicians publish medical studies in full, merely withholding the patients' names. See Lora, 74 F.R.D. at 581 ("Although medical practitioners maintain that their discipline mandates strict confidentiality, they have regularly published patients' case histories in both scientific journals and the popular press."); Freed, $A$ Legal Structure for a National Medical Data Center, 49 B.U.L. REv. 80, 81 (1969) (discussing obligation of national medical data center to withhold patient identities and other information).

68. See Lora, 74 F.R.D. at 580 ("[M]ost persons protest not the mere disclosure of private, embarrassing or damaging information, but rather the concomitant disclosure of identifying data.").

69. 705 F.2d 261 (7th Cir. 1983).

70. Id. at 261-62; Zuniga, 714 F.2d at 634 .

71. Pebsworth, 705 F.2d at 262.

72. $I d$.

No evidentiary privilege is absolute. For a general discussion of the qualifications to which the psychotherapist-patient privilege is subject, see S. HERR, S. ARONS \& R. WALLACE, LEGAl. RiGHTS 
limited purposes of the investigation. ${ }^{73}$ Nevertheless, the court qualified its action with the following instruction: "We trust, however, that the grand jury, related investigative bodies, and, if an indictment is returned, the trial court, will take scrupulous ineasures to ensure that there occurs no unnecessary disclosure of patients' names or diagnoses."74

Although neither Lora nor Pebsworth extended the psychotherapistpatient privilege to bar the production of docuinents necessary to a criminal investigation, each acknowledged the importance of protecting patient identity in the course of psychiatric treatment. The federal courts, however, have failed to include identity within the protective scope of the psychotherapist-patient privilege. In contrast, the federal courts have chosen to protect individual identity in analogous situations. ${ }^{75}$ The policies behind these protected relationships are coinparable to those warranting protection of identity in the psychotherapist-patient relationship.

\section{ANALOgOUS Relationships IN Which ANONYMITY IS PRESERVED}

In at least three situations, the federal courts have protected individual identity in order to preserve a confidential relationship. These cases have involved the journalist-source relationship, ${ }^{76}$ the governinent informant, 77 and, in specific circumstances, the attorney-client relationship. ${ }^{78}$ Each of these relationships benefits society as a whole, ${ }^{79}$ and is endangered to some degree when identities are released. In the above situations, courts have afforded anonymity when disclosure of identity would place individuals in danger ${ }^{80}$ or would subject them to undue harassment or prejudice. ${ }^{81}$

Similar considerations apply in the case of the psychotherapist-patient relationship. Patients undergoing treatment will inore readily reveal their inner thoughts and emotions if assured of confidentiality. ${ }^{82}$ In

AND MenTal Health CARE 98 (1983). Yet it is questionable whether filing an insurance reimbursement claim should be deemed a waiver of the psychotherapist-patient privilege. For the argument that "the traditional waiver doctrines are inappropriate in the context of present day medical imsurance," see Pebsworth, 705 F.2d at 264 (Gray, J., concurring). See also Note, Privilege, supra note 8 , at $397 \mathrm{nn} .101-03$.

73. Pebsworth, 705 F.2d at 264.

74. Id. at 264 (emphasis added).

75. See infra notes $85-143$.

76. See infra notes $85-99$ and accompanying text.

77. See infra notes 100-21 and accompanying text.

78. See infra notes $122-43$ and accompanying text.

79. See infra notes $88,99,101,122$ and accompanying text.

80. See infra notes $94,103,104,118$ and accompanying text.

81. See infra notes $103,104,118,121,128-34$ and accompanying text.

82. See supra notes $36,38-40$ and accompanying text. 
addition, because of the social stigma attaching to the patient in psychotherapy, patients must be guaranteed anonymity if they are to be encouraged to seek treatment. ${ }^{83}$ Thus, as the following analogies illustrate, judicial protection of a patient's identity is necessary to ensure successful treatment, which benefits not only the individual patient, but society as a whole. ${ }^{84}$

\section{A. The Journalist's Source.}

As in the psychotherapist-patient relationship, trust is the foundation for the alliance between a journalist and a confidential source. ${ }^{85}$ If confidentiality of the source's identity is not guaranteed, then the potential harm to the source ${ }^{86}$ discourages formation and continuation of the journahist-source relationship. ${ }^{87}$ In addition, exposure will deter sources from approaching the press with information, thus chilling the free flow of news to the public. 88

The journalist-source privilege was not recognized at common law because it was thought that the privilege did not satisfy Wigmore's four criteria: ${ }^{89}$ the very purpose of the relationship is to permit public disclosure of the source's information. At least two commentators, however, have detected a flaw in that analysis. Journalists do not seek a privilege against disclosure of confidential communications, but of the source's identity. 90 The commentators reason that Wigmore's criteria would be satisfied if apphed to the informant's identity alone. ${ }^{91}$

83. See supra notes $21,42,51,53-57$ and accompanying text.

84. See supra note 43 and accompanying text.

85. Branzburg v. Hayes, 408 U.S. 665,669 n.5 (1972).

86. See infra notes $94-95$ and accompanying text.

87. See infra notes $97-98$ and accompanying text.

88. See, e.g., Baker v. F \& F Inv., 470 F.2d 778, 782 (2d Cir. 1972) ("The deterrent effect such disclosure [of confidential sources] is. likely to have upon . . . reporting . . threatens freedon of the press and the public's need to be informed."), cert. denied, 409 U.S. 1125 (1973); Carter, The Joumalist, His Informant and Testimonial Privilege, 35 N.Y.U. L. REV. 1111, 1124 (1960) ("It is in the public interest for informants to inform newspapermen. Some informants may be inhibited from doing so, unless they can be confident that their own identities will be kept secret.").

89. See supra note 30 and accompanying text; Guest \& Stanzler, The Constitutional Argument for Newsmen Concealing Their Sources, 64 Nw. U.L. REv. 18, 26 (1969). The authors explain: "Courts are not always explicit in citing Wigmore, but the grounds which they give invariably indicate a failure to meet at least one of the four conditions." Id. at $26 \mathrm{n.46.}$

90. See Guest \& Stanzler, supra note 89 , at 27 . Guest and Stanzler contend:

[A] literal application of Wigmore's conditions to the issue of the newsman's privilege borders on sophistry and drastically miscontrues the problem. The newsman is not claiming a privilege to conceal the basic information communicated to him by the informant. He is claiming to conceal only the identity of the source and nothing more.

Id. (emphasis added).

91. First, the source divulges his name to the journalist with the expectation of confidentiality; second, anonymity is essential to the relationship because the source will not provide information without it; third, fostering the relationship is essential in order to facilitate the free flow of informa- 
Because the privilege was rejected at common law, its proponents have resorted to constitutional claims grounded in the first amendment m order to protect source identity. ${ }^{92}$ Thus the debate has focused on the claim that failure to protect source identity threatens the free dissemination of news to the public. In addressing this claim, federal courts have evaluated the potential mjury to the individual source and to the journalist-source relationship, and many liave concluded that a qualified journalist-source privilege protects the identity of a confidential source. ${ }^{93}$

tion to the community; and finally, under many circumstances, the injury to the relationship by disclosure of identity outweighs the social benefits gained by the quick resolution of litigation. Id.

92. Id. passim. In Branzburg v. Hayes, 408 U.S. 665 (1972), the Supreme Court first addressed the journalist-source relationship from a constitutional perspective. Branzburg involved a newsman who published an article describing the activity of confidential sources involved in synthesizing hashish from marijuana. Id. at 667 . Branzburg was subpoenaed by a Kentucky grand jury, and although he appeared, he refused to identify the individuals involved in the criminal activity, claiming that the first amendment conferred on him a journalist-source privilege. Id. at 670-71.

The issue in Branzburg, as defined by the Court, was "whether requiring newsmen to appear and testify before state or federal grand juries abridges the freedom of speech and press guaranteed by the First Amendment." Id. at 667. Petitioners' argument focused on the claim that to facilitate complete and accurate news-gathering, agreements to keep a source's identity confidential were necessary; if disclosure to the grand jury of a source's identity is compelled, sources "will be measurably deterred from furrishing publishable information, all to the detriment of the free fiow of information protected by the First Amendment." Id. at 680. The Court, however, declined to grant the newsmen a privilege against testifying before the grand jury because the criminal activity of the source was at issue. Id. at 690 . Throughout the opinion, however, the Court acknowledged that, where the source was not involved in criminal activity, the government's interest in disclosure would be weakened. The majority conceded that innocent sources "may fear that disclosure will threaten their job security or personal safety or that it will simply result in dishonor or embarrassment." Id. at 693.

The federal courts quickly reacted to Branzburg, confining the decision to its facts. For example, in Baker v. F \& F Inv., 470 F.2d 778 (2d Cir. 1972), cert. denied, 409 U.S. 1125 (1973), the United States Court of Appeals for the Second Circuit held that federal law and public policy do not require across-the-board disclosure of confidential sources whenever the disclosure issue is raised. Id. at 781. Baker declared Branzburg inapposite in a civil setting, where courts will often find "the public interest in non-disclosure of journalists' confidential news sources . . . weightier than the private interest in compelled disclosure." Id. at 785.

Baker, id. at 784, directs attention to Justice Powell's concurring opinion in Branzburg, 408 U.S. at 709-10. Powell's concurrence emphasized the "limited nature of the Court's holding," indicating that analysis of all cases, including criminal cases, would be undertaken on a case-by-case basis. Id. at 709-10 (Powell, J., concurring). Stewart's dissent sets forth the policy considerations relevant to such an analysis. These considerations include the belief that it is "obvious that the promise of confidentiality may be a necessary prerequisite to a productive relationship between a newsman and his infornants." Id. at 729 (Stewart, J., dissenting). This dissent also notes that some sources require confidentiality "because of a reasonable fear of reprisals or censure for unorthodox views." Id. at 729-30. Finally, consideration is given to the source's lack of personal involvement in the criminal conduct at issue. Id.

93. See, e.g., Zerilli v. Smith, 656 F.2d 705, 714 (D.C. Cir. 1981); Bruno \& Stillman, Inc. v. Globe Newspaper Co., 633 F.2d 583, 596 (1st Cir. 1980); Miller v. Transamerican Press, Inc., 621 F.2d 721, 725 (5th Cir. 1980), cert. denied, 450 U.S. 1041 (1981); Riley v. City of Chester, 612 F.2d 708, 715 (3d Cir. 1979); Silkwood v. Kerr-McGee Corp., 563 F.2d 433, 437 (10th Cir. 1977); United States v. Steclhammer, 539 F.2d 373, 374-75 (4th Cir. 1976), aff'd, 561 F.2d 539 (1977); Baker v. F 
Both courts and commentators have noted that injury may befall the confidential source as well as the journalist-source relationship if identity is disclosed. The individual source desires anonyinity, particularly when furnishing sensitive information that could lead to retribution. ${ }^{94}$ Although the policy behind the journalist-source relationship is geared toward the free flow of information to the public, and tlius has constitutional implications, the value that anonymity holds for the individual source is also an important consideration. ${ }^{95}$

The federal courts, especially in civil cases, ${ }^{96}$ are sympathetic to the

\& F Inv. 470 F.2d 778, 783 (2d Cir. 1972), cert. denied, 411 U.S. 966 (1973); Gulliver's Periodicals v. Charles Levy Circulating Co., 455 F. Supp. 1197, 1199 (N.D. Ill. 1978).

The first case to discuss the protection of identity for a journalist's source was Garland v. Torre, 259 F.2d 545 (2d Cir.), cert. denied, 358 U.S. 910 (1958). The Garland court refused to protect the identity of the source involved because the identity "went to the heart of the plaintiff's claim." Id. at 550. Similarly, later cases have refused to protect a source's identity where it was central to the plaintiff's cause of action. See, e.g., Carey v. Hume, 492 F.2d 631, 637 (D.D.C. 1974) (identity not protected because "critical to appellee's claim"). Conversely, in Baker v. F \& F Inv., 470 F.2d 778, 783-84 (2d Cir. 1972), cert. denied, 411 U.S. 966 (1973), the United States Court of Appeals for the Second Circuit indicated that there is no reason to disclose identity when it is only tangentially related to the case.

94. See Branzburg v. Hayes, 408 U.S. 665,693 (1971) (confidential sources "may fear that disclosure will threaten their job security or that it will simply result in dishonor or embarrassment"); Cerrito v. Time, Inc., 302 F. Supp. 1071, 1074-76 (N.D. Cal. 1969) (source's identity protected when court record showed that source was subject to "known and imniediate danger"); see also Note, Source Protection in Libel Suits After Herbert v. Lando, 81 CoLuM. L. REv. 338, 341-42 (1981):

[W] hen the information imparted is sensitive, or the individual is in a vulnerable position, a source may be willing to supply information on a confidential basis only. When courts order journalists to disclose the identities of confidential sources in libel suits, the consequences are likely to inhibit both journalists and sources in providing information to the Id. public.

95. One commentator conducted an empirical study of journahists to determine, among other things, whether the journalists believed it was more iniportant to protect the identity of sources, or the contents of their communications. Blasi, The Newsman's Privilege: An Empirical Study, 70 Mich. L. REv. 229, 277 (1971). The overwhelming majority (91\%) of those that responded to the question stated that identity required more complete protection. Id. at 278 . The commentator noted that:

Most of the persons whom I personally interviewed confirmed this preference. Several of these newsmen, however, considered the question a Hobson's choice. They stressed the point that both categories are iniportant and that, if a newsman's privilege is to be qualified, the exceptions should be constructed along lines other than this dichotomy between identity and contents.

Id. For additional discussion of the value of source anonymity in the journalist-source relationship, see, e.g., Case Comment, Freedom of the Press-Reporter Has First Amendment Right to Refuse to Appear and Testify Before Grand Jury About Confidential Sources and Information-Caldwell v. United States, 84 HARV. L. REV. 1536, 1538 (1971).

96. Courts discussing the journalist-source privilege often state, in deference to the Supreme Court's holding in Branzburg v. Hayes, 408 U.S. 665 (1972), that protection of a source's identity is more justifiable in civil litigation than in a criminal proceeding. In Baker v. F \& F Inv., 470 F.2d 778, 784 (2d Cir. 1971), cert. denied, 411 U.S. 966 (1973), however, the Second Circuit noted that, in his Branzburg concurrence, Justice Powell "emphasized the limited nature of the Court's holding, 
protection of source identity in the journalist-source relationship. For example, in Gilbert v. Allied Chemical Corp., ${ }^{97}$ a federal district court in Virginia observed that for effective reporting, a newsnian may have to agree to keep his source confidential. If he is forced to disclose his source, "the sources so disclosed, other confidential sources of other reporters, and potential confidential sources will be significantly deterred from furnishing further information to the press." 98 In addition, the quality and utility of the information given inay decline. ${ }^{99}$

The concerns expressed by the court in Gilbert reflect the same policies involved in the psycliotherapist-patient relationship. Like a journalist's source, a patient in need of psycliotlerapy will hesitate to disclose information without a gnarantee of confidentiality witl regard to identity. Moreover, once the relationship is established, the success of therapy depends on the patient's ability to speak freely about thouglits and feelings, including tliose deemed socially unacceptable. The possibility of identity disclosure and of the concurrent exposure of emotional or psychological infirmities requiring treatnent substantially weakens the psychotherapist-patient relationship.

Furthermore, as it does in the case of the confidential source, public pohicy demands anonymity for psycliotherapy patients. A source's identity is protected to facilitate the gathering of miportant news. Moreover, if a reporter inust divulge a source's identity, other informers are put on

and expressly stated that in his view Branzburg did not compel a journalist 'to give information bearing only a remote and tenuous relationship to the subject of the [grand jury] investigation.' "Id. (quoting Branzburg, 408 U.S. at 710 (Powell, J., concurring)). In his concurrence, Powell declared:

The asserted claim to privilege should be judged on its facts by the striking of a proper balance between freedom of the press and the obligation of all citizens to give relevant testimony with respect to criminal conduct. The balance of these vital constitutional and societal interests on a case-by-case basis accords with the tried and traditional way of adjudicating such questions.

In short, the courts will be available under circumstances where legitimate First Amendment interests require protection.

Branzburg, 408 U.S. at 710 (emphasis added). Many courts view Powell's concurrence as the "key" to the decision. Goodale, Branzburg v. Hayes and the Developing Qualified Privilege for Newsmen, 26 HASTINGS L.J. 709, 716-17 (1975). See, e.g., Baker v. F \& F Inv., 470 F.2d 778, 784 (2d Cir. 1972), cert. denied, 411 U.S. 966 (1973); Gilbert v. Allied Chem. Corp., 411 F. Supp. 505, 510 (E.D. Va. 1976); A picello v. McNeil Laboratories, 66 F.R.D. 78, 83 (E.D.N.Y. 1975); Loadholtz v. Fields, 389 F. Supp. 1299, 1301-02 (M.D. Fla. 1975); Democratic Nat'1 Comm. v. McCord, 356 F. Supp. 1394, $1397-98$ (D.D.C. 1973).

97. 411 F. Supp. 505, 508 (E.D. Va. 1976).

98. Id. See also Apicella v. McNeil Laboratories, 66 F.R.D. 78, 84 (E.D.N.Y. 1975) ("[P]rotection of the identity of sources is often essential to the willingness of these sources to give information to the press....").

99. One commentator notes that: "[G]ood reporting frequently depends on sources who will relax and speak in a spontaneous, expansive, and candid fashion. . . . [Doubt as to the confidentiality of identity] can introduce into the relationship a self-consciousness and guardedness that may preclude the possibility of in-depth, interpretive coverage." Blasi, supra note 95, at 266. 
notice of the occurrence, and the unwillingness to provide information becomes widespread, to the detriment of the public. These observations are also pertinent to the case of the psychotherapy patient. If patient identity is revealed, others seriously in need of therapy are, as a group, deterred from seeking treatment. It is therefore in the public interest to allow the fact of treatment to remain confidential so that potential patients receive the treatment they need.

\section{B. Government Informants.}

The federal courts have historically recognized the value of government informants, and protected their identities. ${ }^{100}$ The Supreme Court has stated that the courts must recognize the testimomal privilege in order to encourage citizens to inform the government about the commission of crimes. 101 Regardless of the informant's motivation-"good citizenship, promise of leniency, or prospect of pecuniary reward"102 such communications are voluntary. The informant "condition[s] his cooperation on an assurance of anonymity-to protect himself and his family from harm, to preclude adverse social reactions and to avoid the risk of defamation or malicious prosecution actions against him."103

Policies supporting confidentiality of an informant's identity can be classified into two separate but related categories. In the first category, confidentiality serves to protect the sources, who may perceive a threat to their own physical safety, or fear acquiring a reputation in the community as a "squealer" or "stool pigeon." 104 In the second category, confidentiality of a source's identity enhances the government's ability to enforce the law; the disclosure of an informant's identity would discour-

100. See Roviaro v. United States, 353 U.S. 53, 55, 67 (1956); Scher v. United States, 305 U.S. 251,254 (1938) ("[P]ublic policy forbids disclosure of an informer's identity unless essential to the defense . . . ."); In re Quarles, 158 U.S. 532, 535-36 (1895) ("It is the right [and] the duty of every citizen . . . to comnunicate to the executive officers any information which he has of the comunission of an offence against [the] laws; and such information is a privileged and confidential communication . . . ."); Vogel v. Gruaz, 110 U.S. 311, 316 (1884) (similar).

101. McCray v. Illinois, 386 U.S. 300,308 (1967) (quoting 8 J. W1GMORE, supra note 30 , § 2374, at 761-62). It is generally believed that the privilege belongs to the government, so that it nuay safeguard its lines of communication with those who are privy to information about violations of the law. See, e.g., Roviaro v. United States, 353 U.S. 53, 59 (1957). McCormick posits, however, that the informant himself nay invoke the privilege. See C. MCCORM1CK, EvidENCE, § 111, at 270 (3d ed. 1984) and the cases cited therein.

I02. McCray v. Illinois, 386 U.S. 300, 308 (1967) (quoting 8 J. WIGMORE, supra note 30 , $\$ 2374$, at 761-62).

103. Id.

104. See e.g., Gutterman, The Informer Privilege, 58 J. CRIM. L. CRiminologY \& POLICE SCl. 32, 34 (1967) ("A nuost coinpelling deterrent against informing is the simister connotation of the word itself. The informant resents being referred to as a squealer, stoolie, rat, stool pigeon, squawker, or in similar terms."). 
age other potential informants from reporting crimes. ${ }^{105}$

The common law developed an almost absolute right ${ }^{106}$ to protect the identity of an informer who simply relayed incriminating information. ${ }^{107}$ This view was inodified, however, by Roviaro v. United States, 108 the seminal case regarding this privilege in the federal courts. Roviaro involved an appeal from a conviction for possession and illegal transportation of heroin. The trial court sustained the government's refusal to disclose the identity of an undercover informant. ${ }^{109}$ The Umited States Court of Appeals for the Seventh Circuit affirmed, ${ }^{110}$ but the Supreine Court reversed. The Court held that the government must disclose an informant's identity if it is "relevant and helpful to the defense of an accused, or is essential to a fair determination of a cause."111 The Court said that "no fixed rule" should govern disclosure of identity;"12 rather, a court should balance, on a case-by-case basis, the public's interest in law

105. See 8 J. W1GMORE, supra note 30 , § 2374, at 761-62. The Supreme Court clearly advocated these policies, and included within article $V$ of the Proposed Rules of Evidence a specific testimonial privilege, Rule 510, protecting the identity of the informant. Proposed Rule 510 provided im pertinent part:

(a) Rules of privilege. The government or a state or subdivision thereof has a privilege to refuse to disclose the identity of a person who has furnished information relating to or assisting in an investigation of a possible violation of law to a law enforcement officer or member of a legislative committec or its staff conducting an investigation.

(b) Who may claim. The privilege may be claimed by an appropriate representative of the government, regardless of whether the information was furnished to an officer of the government or of a state or subdivision thereof. The privilege may be claimed by an appropriate representative of a state or subdivision if the information was furnished to an officer thereof, except that in criminal cases the privilege shall not be allowed if the government objects.

Proposed Rule 510, 56 F.R.D. 183, 255 (1973).

106. Every common law privilege is subject to certain limitations. Limitations on the inforniant privilege include, but are not limited to, the following: (1) It applies ouly to the informant's identity, not to communications; (2) the party can voluntarily or constructively waive the privilege if his identity is already known to the adversary; and (3) the privilege only applies when the informant communicates to a party having the "responsibility or duty to investigate or to prevent public wrongs." $8 \mathrm{~J}$. WIGMORE supra note $30, \S 2374(\mathrm{f})$, at 765-67 (emplasis in original).

107. See, e.g., Portomene v. United States, 221 F.2d 582, 583-84 (5th Cir. 1955) (identity of informant who inerely gives information can be protected); United States v. Conforti, 200 F.2d 365, 367 (7th Cir. 1952) ("[C]ommunications inade by informers to the Government are privileged."); Sorrentino v. Umited States, 163 F.2d 627, 628-29 (9th Cir. 1947) (distinguishing between inforniers who merely give infornation and whose identity can be protected, and inforners who take part in the crime for which defendant is charged and whose identity is not privileged).

108. 353 U.S. 53 (1957). Roviaro involved the identity of an undercover informer who was instrumental in setting up the arrest of the accused. Specifically, the inforner aided the police by executing a drug pick-up, in concert with petitioner, that was witnessed by narcotics agents. See id. at 56-57.

109. See United States v. Roviaro, 229 F.2d 812, 813 (7th Cir. 1956) (trial court decision unreported).

110. Id. at 816 .

111. Roviaro, 353 U.S. at $60-61$.

112. Id. at 62 . 
enforcennent against the defendant's right to prepare his case. ${ }^{113}$

In general, disclosure of identity has been required by the federal courts if the informant and the defendant were the only participants in the transaction, ${ }^{114}$ if the informant played an active role in the crime charged, ${ }^{115}$ "if the [informant] is a inaterial witness on the issue of guilt" or innocence, ${ }^{116}$ or if the informant's credibility is in question. ${ }^{117}$ Absent such circuinstances, the informant's identity is privileged where necessary to protect him from danger or embarrassment, ${ }^{118}$ to encourage him to continue to provide information helpful to law enforcement officials, and to encourage the activity of other informers. ${ }^{119}$

Psischotherapy patients are similar in relevant respects to government informants. An informant's communications are voluntary and serve the public by aiding law enforcement officials. Exposure of one informant's identity would discourage others froin stepping forward. 120 Similarly, patients generally seek psychiatric treatment on a voluntary basis. The result generally benefits not only the patient, but the commumity as well. In addition, the assurance of anonymity encourages people

113. Id. The court's balancing process should take "into consideration the crime charged, the possible defenses, the possible significance of the informer's testinony, and all other relevant factors." Id.

An in camera hearing inay be employed so that the judge inay hear testimony relevant to the balancing process. See Uinited States v. Fischer, 531 F.2d 783, 788 (5th Cir. 1970) (remanding case and requirimg in camera hearing to determine "the interests which the government may have in resisting ... production [of the informer]," and the relative importance of the informer's testiInony); Uinted States v. Day, 384 F.2d 464, 465, 467 (3d Cir. 1967) (in camera session with informer held; concurring opinion notes that judge inquired whether informant was in danger of physical harm and whether his testiniony would assist defendant).

114. See Roviaro, 353 U.S. at 64 ("This is a case where the Government's informer was the sole participant, other than the accused, in the transaction charged. The informer was the only witness in a position to amplify or contradict the testimony of government witnesses.").

115. See id. at 64; United States v. Whitley, 734 F.2d 1129, 1138 (6th Cir. 1984) (identity protected where informant did not participate in drug transaction); United States v. Ayala, 643 F.2d 244, 246 (5th Cir. 1981) ("The inore active the [informants'] participation, the greater the need for identification."); United States v. Clark, 482 F.2d 103, 104 (5th Cir. 1973) (identity protected where informant did not participate in illegal transaction).

116. $8 \mathrm{~J}$. W1GMORE, supra note $30, \S 2374(f)(4)$, at 768 ; see McCray v. Illinois, 386 U.S. 300,305 (1966); Roviaro, 353 U.S. at 64; Gaines v. Hess, 662 F.2d 1364, 1368 (10th Cir. 1981) (if identity of informant is critical to defense, constitntional due process requires disclosure).

117. 8 J. W1GMoRE, supra note $30, \S 2374(f)(4)$, at 768-69. See generally Smith v. Illinois, 390 U.S. 129, 131, 133 n.8 (1967) (holding Roviaro inapplicable if informant testifies at trial as witness for the prosecution; in such a case, prosecution must reveal the identity if informant's credibility is in issue); United States v. Tucker, 380 F.2d 206, 211 (2d Cir. 1967) (disclosure of identity required "only where independent evidence was so insubstantial" that rehiability of informant is sole basis of all evidence).

118. See supra note 104 and accompanying text.

119. See Note, The Privilege of Withholding the Identity of an Informer, 28 U. PITT. L. REv. 477,477 (1967) (sununarizing objectives served by protecting informants' identities).

120. See supra note 105 and accompanying text. 
to consult psychotherapists without fear of social stigma; exposure of one patient's identity could deter others from seeking needed treatment.

Applymg the Roviaro analysis, psychiatric patients are seldom active participants in the transaction under investigation, and, if called to the stand, would rarely contribute material testimony. In contrast to the situation of a government informant, neither the patient's reliability nor his credibility is in issue. Furthermore, just as an informant fears the brand of "squealer" or "stoolie" if his identity is revealed,"121 the patient undergoing psychotherapy fears the badge of "crackpot" or "lunatic," if his identity goes unprotected. Yet an informant's identity is privileged while the psychotherapy patient's identity is not. These analogies demonstrate that the psychiatric patient's identity merits protection comparable to that given the identity of the government informant. A psychiatric patient is entitled to remain anonymous in judicial proceedings to which the patient has ouly a tenuous relationship.

\section{Attorney-Client Privilege.}

Another situation in which the federal courts have protected individual identity is the attorney-chent relationship. ${ }^{122}$ While a court's goal in litigation is to uncover the truth, the client's goal is to obtain "adequate [legal] advice and a proper defense."123 It is accepted that full disclosure is necessary for the lawyer to function effectively, ${ }^{124}$ and that a client will voluntarily disclose more information if assured of confidentiality through the attorney-chient privilege. ${ }^{125}$ This essential concept of trust in the attorney-client relationship is similarly necessary for full disclosure and effective treatment in the psychotlerapist-patient relationship.

As is the case witl all testimomal privileges, the scope of the attorney-client privilege is determined on a case-by-case basis. Although cli-

121. See Gutterman, supra note 104 , at 34 .

122. The Supreme Court has acknowledged that the attorney-client privilege is the oldest testimomal privilege recognized at common law. Upjohn Co. v. United States, 449 U.S. 383, 389 (1980). The Upjohn Court stated that the privilege's "purpose is to encourage full and frank communication between attorneys and their clients and thereby promote broader public interests in the observance of law and the administration of justice." Id.

123. Baird v. Koerner, 279 F.2d 623, 629 (9th Cir. 1960).

124. See Trammel v. United States, 445 U.S. 40, 51 (1979) ("The lawyer-client privilege rests on the need for the advocate . . . to know all that relates to the client's reasons for seeking representation if the professional mission is to be carried out."); see also Fisher v. United States, 425 U.S. 391, 403 (1975) ("The purpose of the privilege is to encourage clients to make full disclosure to their attorney.").

125. Hunt v. Blackburn, 128 U.S. 464, 470 (1888) (attorney's knowledge and skill "can only be safely and readily availed of when free from the consequences or the apprehension of disclosure"). 
ent identity does not normally fall within the scope of the privilege, ${ }^{126}$ the federal courts have estabhshed at least two exceptions to this rule. ${ }^{127}$ The first exception, labeled the "legal advice" exception, holds identity protectable if disclosure "would implicate the chent in the very inatter for which legal advice was sought."128 The second, related exception protects identity if "so inuch of the actual communication has already been disclosed that identification of the chent amounts to disclosure of a confidential communication." 129

The United States Court of Appeals for the Ninth Circuit discussed the "legal advice" exception in United States v. Hodge \& Zweig. 130 In Hodge, the Internal Revenue Service (IRS) summoned certain attorneys to produce a chent's financial records. ${ }^{131}$ At the same time, a grand jury was investigating alleged drug violations by that chent and others. ${ }^{132} \mathrm{Be}-$ cause the tax investigation continued during the criminal prosecution, the lawyers refused to coniply with the IRS summons, claiming the attorney-chent privilege. ${ }^{133}$ Although the court noted that fee information sought for a legitimate purpose is generally not privileged, it recognized that the rule "is qualified by an important exception . . . where the person invoking the privilege can show that a strong probability exists that disclosure of [client identity and fee arrangements] would implicate that client in the very criminal activity for which legal advice was sought."134

126. See, e.g., Gannett v. First Nat'1 State Bank, 546 F.2d 1072, 1073 n.4 (3d Cir. 1976) (absent "unusual circumstances," client identity is not within scope of attorney-client privilege), cert. denied, 431 U.S. 954 (1977).

127. See In re Grand Jury Proceedings (Gordon), 722 F.2d 303, 307 (6th Cir. 1983).

128. See, e.g., id. (quoting In re Grand Jury Subpoenas Duces Tecum (Marger/Merenbacli), 695 F.2d 363, 365 (9tli Cir. 1982)).

129. NLRB v. Harvey, 349 F.2d 900, 905 (4tlı Cir. 1965). Otlier cases that either acknowledge or support this exception include: In re Witnesses Before the Special Marcli 1980 Grand Jury, 729 F.2d 489, 494 (7th Cir. 1984) (disclosure of fees paid by known client is "less likely to reveal confidential coininunications tlian would the revelation of an unknown client's identity"); In re Slaughter, 694 F.2d 1258, 1260 (11th Cir. 1982) (exception applies only to fee information that would expose identity of "previously undisclosed client/suspect"); Colton v. United States, 306 F.2d 633, 637 (2d Cir. 1962) (protection may result "where the substance of a disclosure lias already been revealed but not its source"), cert. denied, 371 U.S. 951 (1963); Baird v. Koerner, 279 F.2d 623, 632 (9tlı Cir. 1960) (client identity is protected if disclosure would convey information that is part of the usual privileged comınunication); United States v. Pape, 144 F.2d 778, 783 (2d Cir.) ("[T]here inay be situations in whicls so nucli has already appeared of tlie actnal communications between an attorney and a client, that the disclosure of the client will result in a breacli of the privilege . . . ."), cert. denied, 323 U.S. 752 (1944).

130. 548 F.2d 1347 (9th Cir. 1977).

131. Id. at 1349 .

132. Id. at 1350 .

133. Id. at $1349-50$.

134. Id. at 1353. The exception derives froin the rule set out in Baird v. Koerner, 279 F.2d 623 (9tlı Cir. 1960), that a client's identity must be protected where disclosure would reveal a confidential communication of the "ultimate motive of litigation." Id. at 630 (citing $8 \mathrm{~J}$. W1GMORE, $\S 2313$ 
United States v. Liebman ${ }^{135}$ is a recent, salient example of the second type of circumstance-the actual communications exception-that supports protection of identity in the attorney-client relationship. The appellants in Liebman were attorneys who evaluated real estate partnerships for chents seeking tax-slelter investnients; they charged fees only to those chients that invested. ${ }^{136}$ The IRS, discovering that some of these clients had deducted the fees as legal expenses on their tax returns, claimed that these payments were not legal fees, but were, in fact, nondeductible brokerage fees. ${ }^{137}$ The agency loped to identify the other clients that liad deducted the fees. Liebman and his firm refused to reveal the names, addresses or social security numbers of the clients, claining the attorney-client privilege. ${ }^{138}$ The United States Court of Appeals for the Third Circuit agreed that the disclosure of the clients' identities would indeed reveal the content of the privileged commumications-that the clients were advised that the fees were tax deductible-and that the identities were therefore protected by the attorney-chent privilege. ${ }^{139}$

The rationales underlying each of these two exceptions could be applied to protect identity in the psychotherapist-patient situation. First, disclosure of identity imphicates the patient in the very nuatter for which treatment was initially sought. Disclosure of a patient's identity in the context of an investigation would reveal that the patient sought treatinent for soine inental or emotional infirmity. The feared social stigina would attach autornatically, labeling the patient as "mentally ill." Second, because of its sensitive nature, the fact that a person is receiving psychotherapy can be likened to a substantive communication between the psychotlerapist and the patient. Thus, disclosure of identity can reveal mental or eniotional infirmity just as disclosure of the identities in Liebman would have revealed income tax evasion.

Whether a client's identity is protected by the attorney-client privilege depends upon the facts of each case. ${ }^{140}$ The leading case articulating this case-by-case analysis in the attorney-chent context is Baird v. Koer-

(3d ed. 1940)). In Hodge, the Baird rule was applied and, preliminarily, appeared to protect identifying information which could have implicated unnamed clients in the drug conspiracy. Hodge, 548 F.2d at 1354. Nevertheless, the court ordered disclosure of the identifying information on otler grounds. Id. at 1355 . The court noted that the government liad established a prima facie case "tliat the attorneys were retained in furtherance of a continuing conspiracy." Id. Applying the "crime or fraud exception" to the attorney-client privilege, the court determined that the information was not protected. Id. at 1354-55.

135. 742 F.2d 807 (3d Cir. 1984).

136. Id. at 808 .

137. Id.

138. Id.

139. Id. at $810-11$.

140. See Baird v. Koerner, 279 F.2d 623, 630-31 (9th Cir. 1960). 
ner. ${ }^{141}$ In Baird, an attorney was asked to reveal the identities and addresses of several clients who employed him to transmit delinquent income tax payinents. The attorney raised the attorney-client privilege, and the United States Court of Appeals for the Ninth Circuit agreed that under the facts of the case, client identity was entitled to protection..$^{142}$ Particularly relevant for the court was the fact that no litigation between the delinquent taxpayers and the IRS existed. The taxpayers had neitlier filed suit against the government nor sought any judicial determination concerning "tlie correctness of the ainount . . . [or even] the fact that any sum [was] owed by them." 143

Often, as the facts of Zuniga sliow, the psychotherapy patient finds himself subject to a dispute which is not of his making. The argument in favor of protection of identity is, in fact, more compelling in the Zuniga context than on the facts of Baird; the psychotherapy patient is even less likely than the delinquent taxpayer to be a party to the litigation. While the courts have protected identity in the attorney-client situation in contexts where disclosure would substantially prejudice the client, they have failed to protect identity under the psychotherapist-patient privilege even though the patient might suffer substantial prejudice. Though disclosure of patients' identities might expedite certain investigations, the damage that would inure to the psychotherapist-patient relationship by the disclosure far outweighs that consideration. The patient undergoing psychotherapy must be accorded anonymity so as not to thwart the prinary goal of the psychotlerapist-patient privilege-uninhibited coinmumication between patient and therapist.

\section{CONCLUSION}

The psycliotlierapist-patient privilege faces two substantial barriers in the federal courts. First, many courts have failed to recognize a psychotherapist-patient privilege at all, because they equate it with the physician-patient privilege-a privilege not recognized at coinınon law. Second, the courts that have recognized the privilege have declined to extend its scope to include protection of a patient's identity.

The standard for recognizing testiunomal privileges under Federal Rule of Evidence 501 justifies the application of a psychotherapist-patient privilege. The psycliotherapy patient is expected to reveal his innerinost thouglits and feelings-which may be irrational or offensive to

141. 279 F.2d 623 (9th Cir. 1960).

142. Id. at 630 .

143. Id. at 630-31. The taxpayers had "merely stated, through an attorney, 'I am worried about my position if the government ever investigates my tax return. Hence $I$ deem it wise to pay $X$ dollars to the government now.' "Id. at 631 . 
others-during the course of psychiatric treatment. The psychotherapist-patient relationship is unlike the general physician-patient relationship in that if a psychotherapy patient is not assured of confidentiality with regard to any information that he reveals, the patient is not likely to cooperate with the psychotherapist, or even to seek treatment.

Moreover, the majority of federal courts addressing the issue have failed to recognize the need for confidentiality as to the fact of treatment, even though the average person fears the social stignia that accoinpanies identification as a psychotherapy patient. This apprehension may hinder successful therapy and deter people froin seeking needed treatment. In several similar situations, however, the federal courts have protected individual identity. The policies behind protection of identity in the analogous situations impel the protection of identity in the psychotherapistpatient relationship.

An absolute privilege of anonymity need not extend to a psychotherapy patient under all circumstances. It is settled law that just as the existence of privileges under Federal Rule of Evidence 501 must be determined on a case-by-case basis, the scope of such privileges must be determined on a case-by-case basis as well. Once a federal court concludes that a psychotherapist-patient privilege should be recognized, the court, in appropriate cases, should also extend Rule 501 protection to a patient's identity, as well as to confidential communications taking place between patient and psychotherapist. In many cases, psychotherapy patients are not parties to the judicial proceedings, have not participated in the activity under mvestigation, and are otherwise only tangentially related to the issues in the case. It is suggested that, where such circumstances exist, courts are presented with an appropriate opportunity for the extension of the psychotherapist-patient privilege to protect a patient's identity. 